\title{
PENGARUH POLA PENGELOLAAN HAMA TERHADAP POPULASI SERANGGA HAMA PADA LAHAN KEDELAI VARIETAS ANJASMORO DAN WILIS
}

\author{
Mahardika Puspitasari ${ }^{1}$, Purnama Hidayat ${ }^{1}$, Pudjianto $^{1}$, Marwoto $^{2}, \&$ \\ Bambang Tri Rahardjo ${ }^{3}$
}

\author{
${ }^{1}$ Departemen Proteksi Tanaman, Fakultas Pertanian, Institut Pertanian Bogor \\ J1. Kamper, Kampus IPB Dramaga, Bogor 16680 \\ ${ }^{2}$ Balai Penelitian Tanaman Aneka Kacang dan Umbi, Badan Penelitian Pertanian \\ ${ }^{3}$ Jurusan Hama dan Penyakit Tumbuhan, Fakultas Pertanian, Universitas Brawijaya \\ Jl. Veteran, Ketawanggede, Lowokwaru, Malang, Jawa Timur \\ E-mail: dhunt.dee@gmail.com
}

\begin{abstract}
Effect of pest management systems to the insect pests population on Anjasmoro and Wilis soybean varieties. The integrated pest management (IPM) is a pest control approach which is based on ecological and economic considerations. The objective of this research was to study the effect of different pest management systems on the insect pest population using two soybean varieties, Anjasmoro and Wilis. The experiments were done in a randomized complete block design, repeated twice. The pest management systems under the different plots were integrated pest management, non-chemical control, chemical control, and the control (which received neither chemicals nor IPM). Observations were made on the pest population and the intensity of the damage caused by primary soybean pests. The primary pests observed were Ophiomya phaseoli, Aphis gossypii, Lamprosema indicata, Spodoptera litura, Bemisia tabaci, Riptortus linearis and Etiella zinckenella. Integrated pest management significantly affect the population of whitefly on Anjasmoro variety but not on Wilis variety. The populations of bean fly, aphid, leaf roller, armyworm, stink bug and pod borer were not affected by pest management system. The lower yield of Anjasmoro variety was attributed to the attack by a viral infection whose disease incidence reached $80 \%$ on the plots without a pest management system. IPM management system was more efficient than chemical management system.
\end{abstract}

Key words: Anjasmoro variety, IPM, population, soybean pest, Wilis variety

\begin{abstract}
ABSTRAK
Pengaruh pola pengelolaan hama terhadap populasi serangga hama pada lahan kedelai varietas Anjasmoro dan Wilis. Pengendalian hama terpadu (PHT) merupakan suatu cara pengendalian hama dan penyakit yang didasarkan pada pertimbangan ekologi dan efisiensi ekonomi yang berwawasan lingkungan dan berkelanjutan. Penelitian ini bertujuan untuk mempelajari pengaruh pola pengelolaan hama terhadap populasi serangga hama pada lahan kedelai varietas Anjasmoro dan Wilis. Percobaan dilakukan dengan Rancangan Acak Kelompok dengan dua ulangan menggunakan kedelai varietas Anjasmoro dan Wilis. Perlakuan pengelolaan hama yang diterapkan adalah pengelolaan hama terpadu, pengendalian non-kimiawi, pengendalian kimiawi, dan kontrol. Masing-masing petak perlakuan berukuran 10 x $10 \mathrm{~m}$. Pengamatan dilakukan terhadap populasi hama utama kedelai. Hama utama yang diamati adalah Ophiomya phaseoli, Aphis gossypii, Lamprosema indicata, Spodoptera litura, Bemisia tabaci, Riptortus linearis dan Etiella zinckenella. Pengendalian hama terpadu mempengaruhi populasi kutu kebul pada varietas Anjasmoro sedangkan pada varietas Wilis pola pengelolaan hama tidak mempengaruhi populasi kutukebul. Populasi lalat kacang, kutudaun, ulat penggulung daun, ulat grayak, kepik penghisap polong dan ulat penggerek polong tidak dipengaruhi oleh pola pengelolaan hama yang berbeda. Produksi kedelai varietas Anjasmoro rendah disebabkan oleh adanya serangan virus dengan insidensi penyakit mencapai $80 \%$ pada petak tanpa perlakuan pengelolaan hama. Pola pengelolaan hama tidak berpengaruh pada hasil produksi. Pola pengelolaan hama terpadu lebih efisien daripada pengelolaan hama kimiawi.
\end{abstract}

Kata kunci: hama kedelai, PHT, populasi, varietas Anjasmoro, varietas Wilis 


\section{PENDAHULUAN}

Lalat kacang Ophiomya phaseoli Tryon (Diptera: Agromyzidae), ulat penggulung daun Lamprosema indicata Fabricius (Lepidoptera: Pyralidae) (Biswas \& Islam, 2012), kutudaun Aphis sp. Glover (Hemiptera: Aphididae) (Radiyanto et al., 2010), kepik penghisap polong Riptortus linearis Fabricius (Hemiptera: Alydidae) (Latif, 2013), ulat penggerek polong Etiella zinckenella Treit (Lepidoptera: Pyralidae) (Berg et al., 2010), kutukebul Bemisia tabaci Gennadius (Hemiptera: Aleyrodidae) dan ulat grayak Spodoptera litura Fabricius (Lepidoptera: Noctuidae) (Biswas, 2013) merupakan hama utama tanaman kedelai yang menyebabkan penurunan produksi di tingkat petani. Hama tersebut mampu menyebabkan kehilangan hasil bahkan puso apabila tidak dikendalikan (Berg et al., 2010).

Upaya peningkatan produksi dapat dilakukan dengan pengendalian hama dan penyakit, perbaikan manajemen usaha tani dan penanganan panen dan pascapanen (Supadi, 2008). Zakaria et al. (2010) menyebutkan bahwa pada tahun 2009 petani kedelai di tiga provinsi yaitu Jawa Barat, Jawa Timur dan Sulawesi Selatan $100 \%$ menggunakan insektisida terutama insektisida yang disemprotkan yaitu sebanyak 6-8 kali aplikasi. Namun, penggunaan pestisida yang tidak bijaksana dapat mengakibatkan resurgensi dan resistensi serangga hama (Latif, 2013). Beberapa penelitian telah dilakukan untuk mencari alternatif penggunaan insektisida sintetik untuk mengendalikan berbagai organisme pengganggu tanaman (OPT) tanaman kedelai. PGPR (Plant Growth Promoting Rhizobacteria) merupakan agensia pengendali hayati yang dapat menekan penyakit di lapangan serta meningkatkan pertumbuhan tanaman (Widodo, 2006). Indiati (2014) meneliti penggunaan insektisida botanis ekstrak mimba yang mampu menekan populasi ulat penggulung daun dan ulat grayak. Arifin (2012) menyatakan bahwa penggunaan Sl-NPV (Spodoptera litura nucleopolyhedro virus) mampu mengendalikan ulat grayak. Tillman (2014) menyebutkan bahwa penggunaan tanaman pinggir mampu menekan pergerakan kepik hijau pada pertanaman kapas. Hasilhasil penelitian tersebut mengenai kemampuan satu jenis pengendalian terhadap satu atau dua jenis hama.Varietas Anjasmoro dan Wilis merupakan varietas yang tahan rebah dan tahan terhadap serangan penyakit karat daun (Suhartina, 2005, Ghulamahdi et al., 2009).

Praktik pengendalian hama dengan insektisida terjadwal dapat menyebabkan berbagai dampak buruk, termasuk dampak terhadap lingkungan. Alternatif pengendalian yang dapat dilakukan adalah melalui pengembangan pengendalian hama terpadu (PHT). Namun, hingga saat ini belum terdapat informasi mengenai pengaruh aplikasi kombinasi prinsip-prinsip PHT yang diterapkan untuk mengendalikan berbagai OPT kedelai di lapangan. Oleh karena itu, perlu dilakukan penelitian untuk mendapatkan pola pengendalian yang efektif dan efisien yang diharapkan dapat diadopsi oleh petani.

Penelitian ini bertujuan mempelajari pengaruh pola pengelolaan hama yang berbeda terhadap populasi serangga hama pada lahan kedelai varietas Anjasmoro dan Wilis.

\section{METODE PENELITIAN}

Tempat dan Waktu. Penelitian ini dilaksanakan di kebun percobaan Balai Penelitian Tanaman Aneka Kacang dan Umbi (BALITKABI) di Desa Ngale, Kecamatan Paron, Kabupaten Ngawi, Provinsi Jawa Timur. Sedangkan identifikasi dan analisis data dilakukan di Laboratorium Taksonomi dan Biosistematika Departemen Proteksi Tanaman, Institut Pertanian Bogor. Penelitian dilaksanakan pada bulan Juni 2013 sampai dengan Mei 2014.

Prosedur Percobaan. Percobaan dilakukan dengan menggunakan Rancangan Acak Kelompok dengan perlakuan pola pengelolaan hama. Percobaan dilakukan terhadap dua varietas unggul kedelai yaitu varietas Anjasmoro dan Wilis. Setiap kombinasi perlakuan diulang sebanyak tiga kali masing-masing pada petak berukuran $10 \times 10 \mathrm{~m}$ atau $100 \mathrm{~m}^{2}$.

Benih varietas Anjasmoro dan Wilis diperoleh dari BALITKABI dan ditanam pada lahan dengan pemberian perlakuan pola pengelolaan hamayang berbeda. Perlakuan tersebut yaitu 1) PHT (pengendalian hama terpadu) yaitu kombinasi antara perendaman benih selama 15 menit dengan PGPR (Bacillus polymixa dan Pseudomonas flourescens; Rhizomax, Wish Indonesia), penanaman jagung sebagai tanaman pinggir pada petak perlakuan, monitoring populasi dan intensitas kerusakan hama, aplikasi pestisida kimia (bahan aktif Klorfluazuron dan Fipronil dengan dosis masing-masing $900 \mathrm{ml} / \mathrm{ha}$ ) dan pestisida botanis ekstrak mimba $5 \mathrm{ml} / \mathrm{L}$ (Azadirachtin; Organeem, Balai Penelitian Tanaman Serat (BALITAS)) sebanyak 5 kali aplikasi berdasarkan hasil pemantauan, 2) P-NK (pengendalian non kimiawi) yaitu kombinasi antara perlakuan benih dengan PGPR, monitoring populasi dan intensitas kerusakan hama, 
aplikasi pestisida botanis (ekstrak Mimba) dan agensia hayati Sl-NPV (Spodoptera litura nucleopolyhedro virus; biakan murni BALITAS) $100 \mathrm{~g} / \mathrm{Ha}$ sebanyak 5 kali aplikasi berdasarkan hasil pemantauan, 3) P-K (pengendalian kimiawi) yaitu aplikasi pestisida kimiawi secara terjadwal (enam kali aplikasi) dan 4) K (kontrol) yaitu tanpa aplikasi pengendalian.

Pengamatan Populasi Hama. Hama kedelai yang diamati pada penelitian ini merupakan hama utama pada tanaman kedelai dari fase yang berbeda di Ngawi (Marwoto, 2007). Hama utama yang diamati yaitu Lalat Kacang Ophiomya phaseoli Tryon (Diptera: Agromyzidae), pengamatan dilakukan sebanyak tiga kali pengamatan dengan menghitung larva yang ditemukan pada 30 rumpun sampel yang berada pada garis diagonal dalam petak pada 7, 14 dan 21 Hari Setelah Tanam/ HST; Kutudaun Aphis gossypii Glover (Hemiptera: Aphididae), pengamatan dilakukan dengan menghitung jumlah A. gossypii yang muncul pada 15 rumpun sampel yang berada pada garis diagonal dalam petak sejak tanaman berumur 7 sampai dengan 70 HST dengan interval tujuh hari (sepuluh kali pengamatan); Ulat penggulung daun Lamprosema indicata Fabricius (Lepidoptera: Pyralidae), pengamatan dilakukan dengan menghitung jumlah $L$. indicata yang ditemukan pada tiga buah petak seluas $1 \mathrm{~m}^{2}$ pada masing-masing petak perlakuan mulai dari 21 sampai dengan 42 HST dengan interval 7 hari (empat kali pengamatan); Ulat grayak Spodoptera litura Fabricius (Lepidoptera: Noctuidae), pengamatan dilakukan terhadap jumlah larva yang ditemukan pada 30 rumpun sampel yang berada pada garis diagonal dalam petak mulai dari 7 sampai dengan 70 HST dengan interval tujuh hari (sepuluh kali pengamatan); Kutukebul Bemisia tabaci Gennadius (Hemiptera: Aleyrodidae), pengamatan dilakukan dengan memasang tiga buah perangkap rekat kuning berukuran $10 \times 25 \mathrm{~cm}^{2}$ pada masing-masing petak perlakuan dengan posisi diagonal. Pemasangan dilakukan mulai 21 sampai dengan 70 HST dengan interval tujuh hari (delapan kali pemasangan); Kepik penghisap polong Riptortus linearis Fabricius (Hemiptera: Alydidae), pengamatan dilakukan dengan mengamati telur, nimfa dan imago yang terdapat dalam petak seluas $1 \mathrm{~m}^{2}$ yaitu tiga baris tanaman sepanjang $1 \mathrm{~m}$ sebanyak tiga petak pada masing-masing petak perlakuan pada 49, 56, 63, dan 70 HST (empat kali pengamatan); Penggerek polong Etiella zinckenella Treit (Lepidoptera: Pyralidae), dilakukan dengan mengambil 10 polong pada 15 rumpun sampel yang berada pada garis diagonal dalam petak pada 49, 56, 63, 70 HST, dan ketika panen (77 HST).
Produksi Kedelai. Panen kedelai dilakukan dengan cara "ubinan" yaitu dengan mengambil rumpun yang berada dalam tiga petak berukuran $2 \times 5 \mathrm{~m}$ pada masingmasing petak percobaan. Biji kering kedelai (dengan kadar air $\pm 18 \%$ ) yang telah terpisah dari pohonnya kemudian ditimbang. Data hasil produksi dianalisis dengan menggunakan sidik ragam, apabila terdapat perbedaan nyata maka dilanjutkan dengan uji Tukey pada selang kepercayaan $95 \%$.

Analisis Data. Data hasil pengamatan populasi serangga hama dianalisis dengan menggunakan sidik ragam dengan tingkat kepercayaan $95 \%$ dengan menggunakan MINITAB 16. Apabila hasil analisis sidik ragam menunjukkan perbedaan nyata maka dilanjutkan dengan uji perbandingan Tukey dengan selang kepercayaan $95 \%$.

\section{HASIL DAN PEMBAHASAN}

Waktu Kemunculan Hama. Serangga hama yang diamati memiliki waktu kemunculan yang berbeda-beda. Perbedaan waktu kemunculan tersebut berkaitan dengan aktivitas makan dan kondisi lingkungan pada pertanaman. Gambar 1 menunjukkan waktu kemunculan hama kedelai pada musim kemarau tahun 2013. Kemunculan hama pada pertanaman kedelai berkaitan dengan fase pertumbuhan tanaman kedelai. O. phaseoli muncul pada awal fase vegetatif tanaman yaitu 14 HST, sedangkan B. tabaci, S. litura dan L. indicata muncul pada pertengahan fase vegetatif (21-35 HST) sampai dengan fase generatif tanaman (42-70 HST). Hama $A$. gossypii, $R$. linearis, dan E. zinckenella merupakan hama yang muncul pada fase generatif tanaman yaitu ketika tanaman telah membentuk bunga dan polong.

Populasi Hama. Hasil pengamatan populasi lalat kacang menunjukkan bahwa pada varietas Anjasmoro, lalat kacang hanya ditemukan pada petak dengan pengendalian kimiawi sedangkan pada varietas Wilis, lalat kacang ditemukan pada petak dengan semua perlakuan (Gambar 2). Hasil pengamatan populasi kutudaun pada Gambar 3 menunjukkan bahwa pola pengelolaan hama yang berbeda pada petak perlakuan tidak memberikan pengaruh nyata terhadap populasi kutudaun pada pertanaman. Hal ini terjadi baik pada varietas Anjasmoro maupun pada varietas Wilis. Populasi kutudaun pada petak perlakuan dengan pola pengelolaan hama PHT sama dengan pada petak dengan perlakuan pengelolaan hama non kimiawi, kimiawi dan kontrol. 
Pengamatan populasi ulat peggulung daun pada petak dengan pola pengelolaan hama yang berbeda menunjukkan bahwa tidak terdapat perbedaan populasi ulat baik pada petak dengan pengelolaan hama PHT, kimiawi, non kimiawi maupun tanpa pengelolaan hama
(Gambar 4). Hal ini terjadi pada pertanaman kedelai varietas Anjasmoro dan juga varietas Wilis. Pola pengelolaan hama yang berbeda juga tidak mempengaruhi populasi ulat grayak. Hasil pengamatan terhadap populasi ulat grayak menunjukkan bahwa pola
A

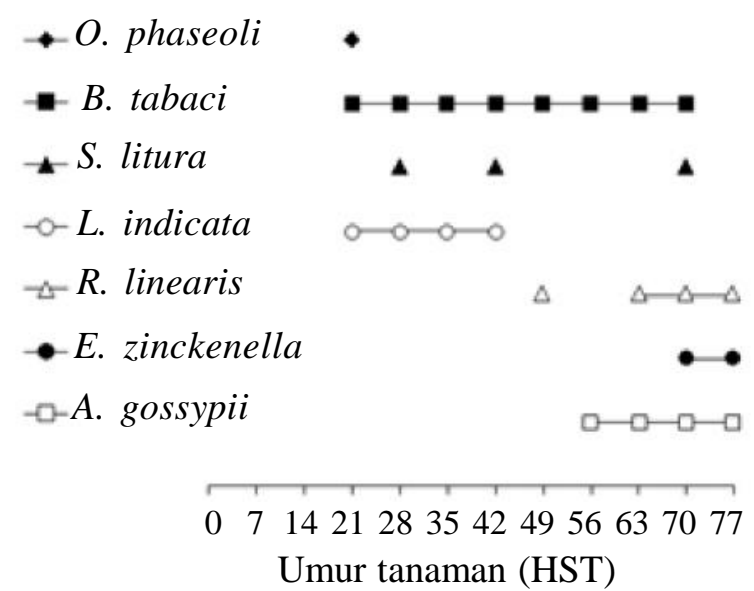

B

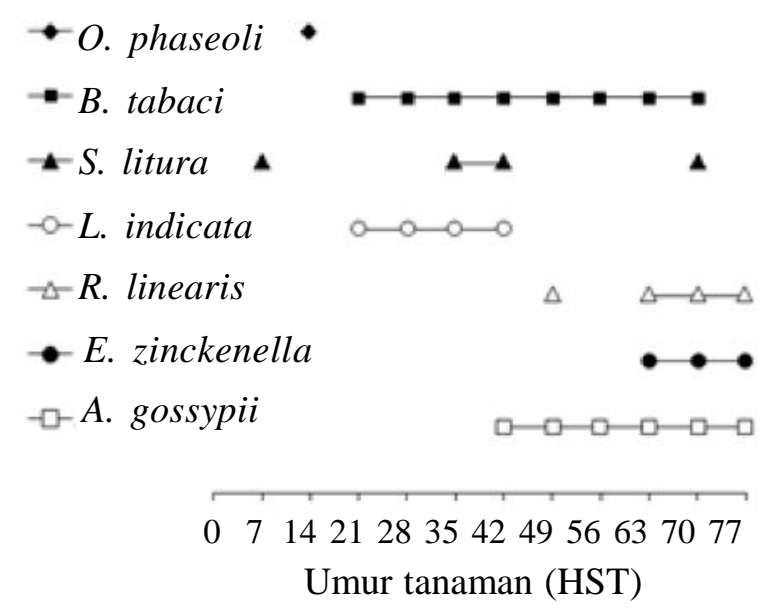

Gambar 1. Waktu kemunculan hama pada varietas Anjasmoro (A) dan Wilis (B) pada semua teknik pengelolaan hama

A

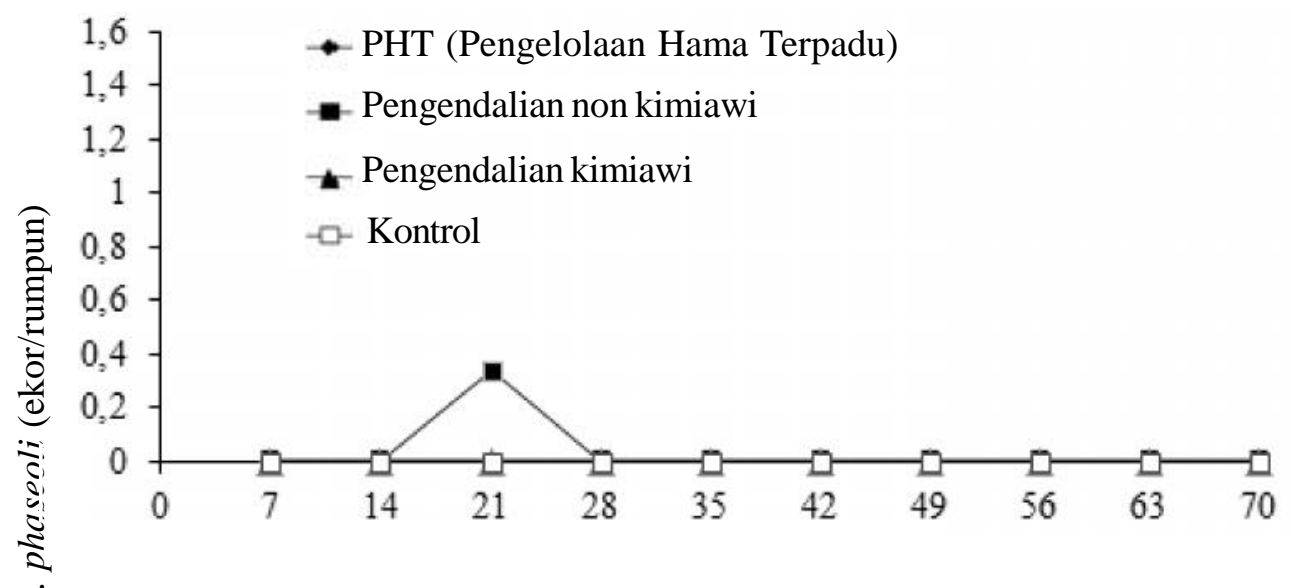

B

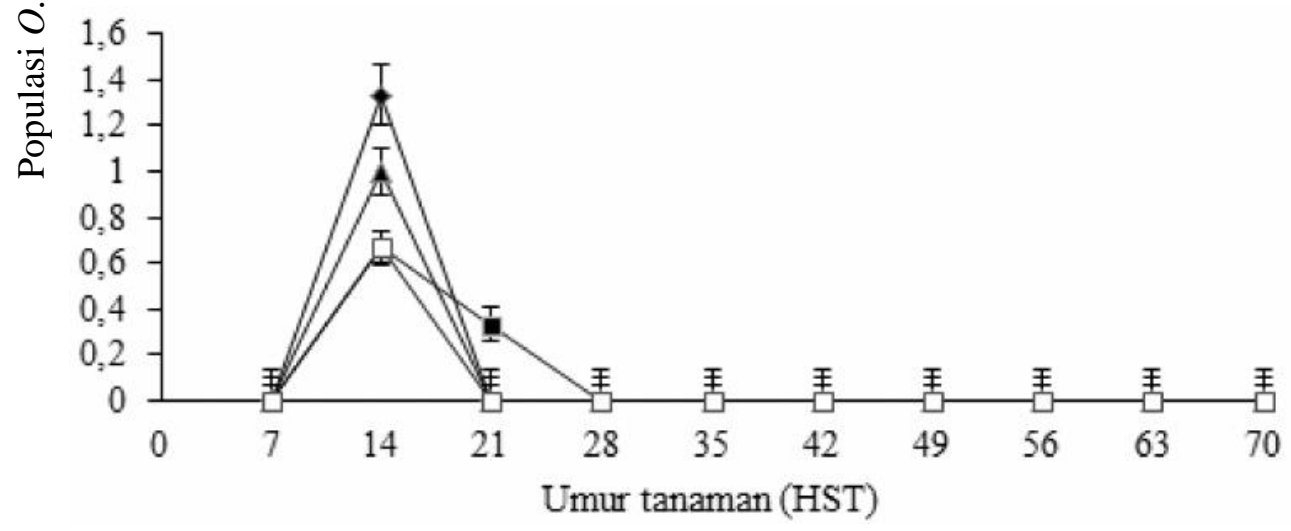

Gambar 2. Populasi larva lalat kacang O. phaseoli pada tanaman kedelai varietas Anjasmoro (A) dan Wilis (B) dalam petak yang menggunakan pola pengelolaan hama berbeda; Garis vertikal pada bar menunjukkan nilai galat baku 


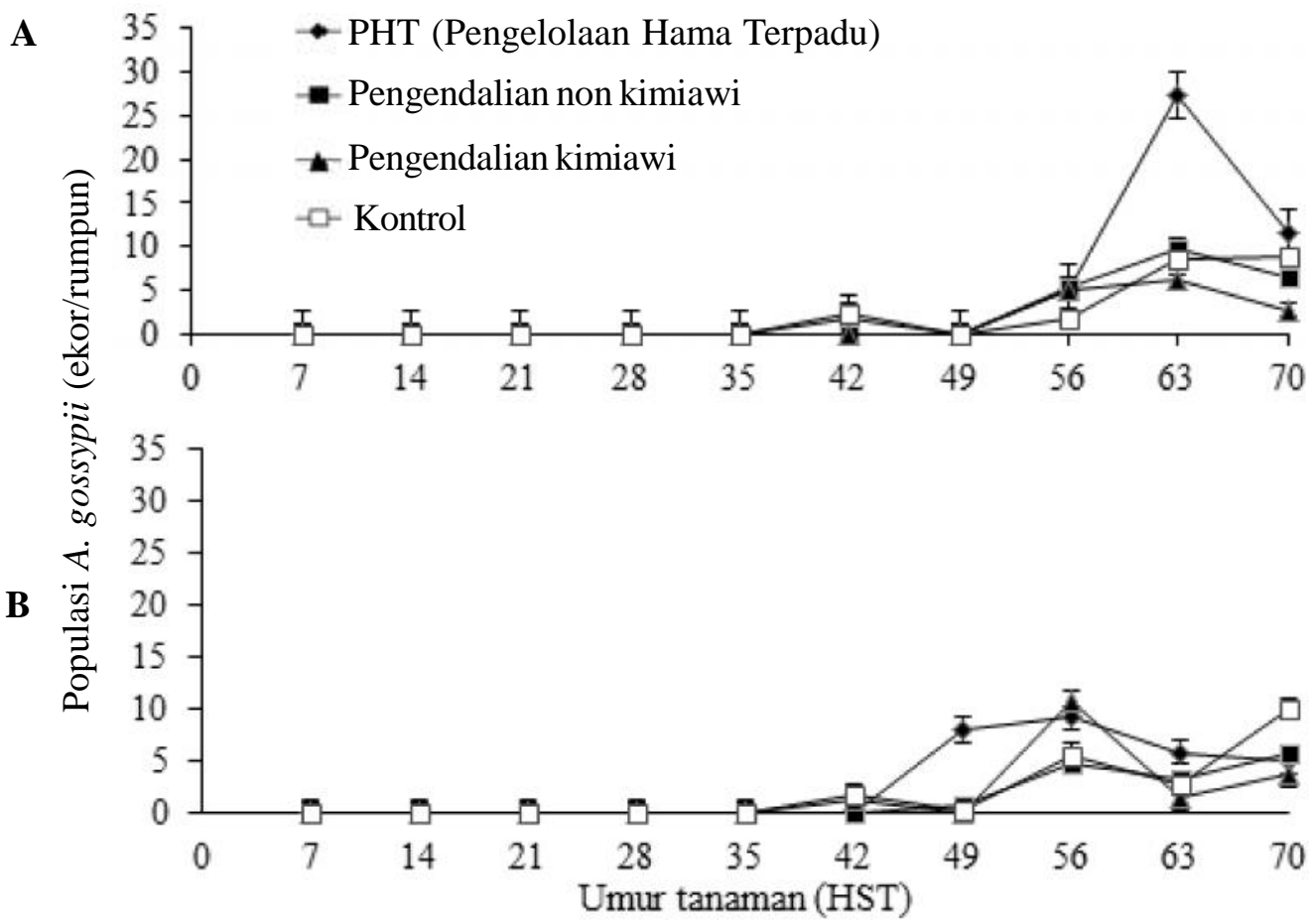

Gambar 3. Populasi kutudaun A. gossypii pada tanaman kedelai varietas Anjasmoro (A) dan Wilis (B) dalam petak yang menggunakan pola pengelolaan hama berbeda; Garis vertikal pada bar menunjukkan nilai galat baku

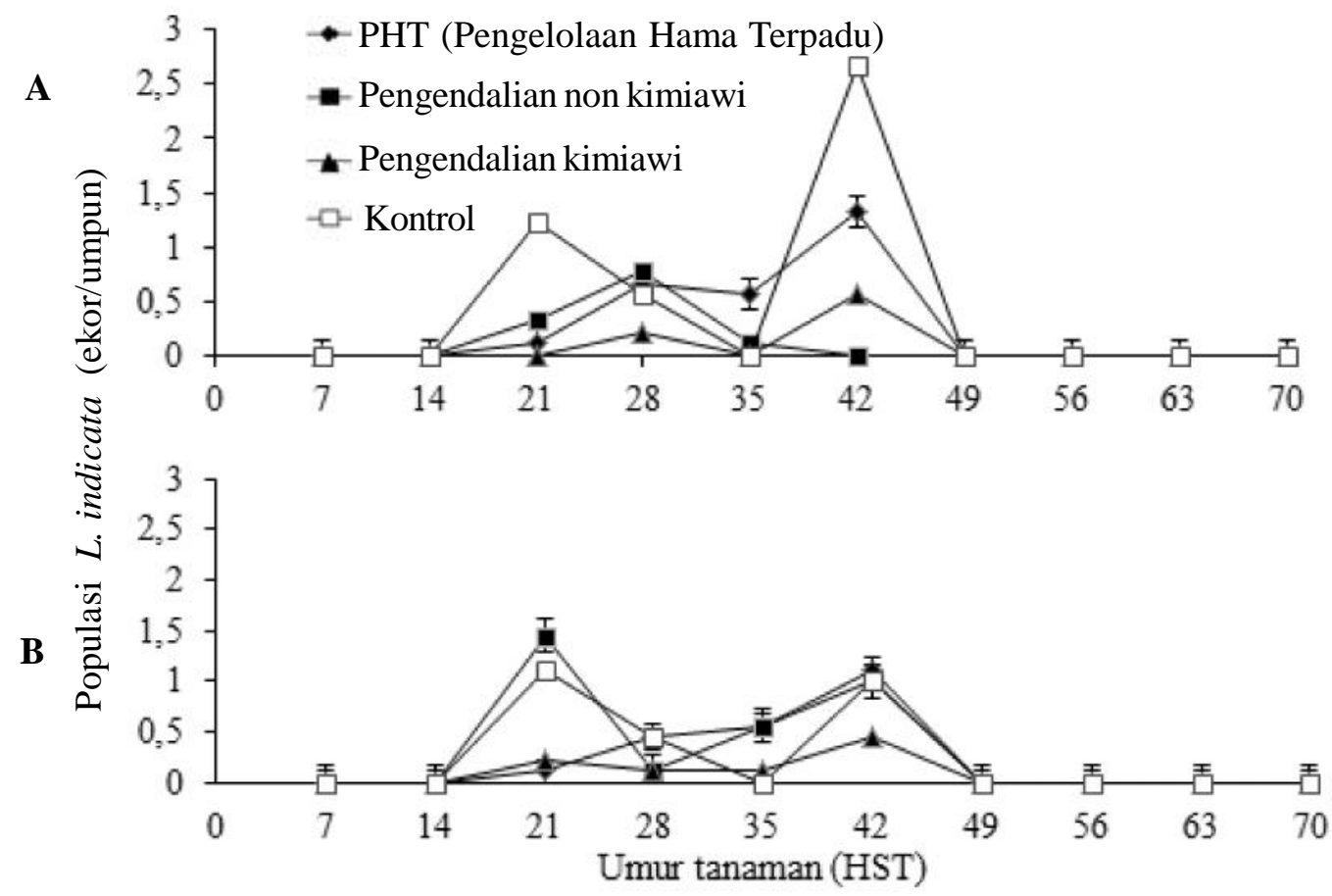

Gambar 4. Populasi kutudaun L. indicata pada tanaman kedelai varietas Anjasmoro (A) dan Wilis (B) dalam petak yang menggunakan pola pengelolaan hama berbeda; Garis vertikal pada bar menunjukkan nilai galat baku 
pengelolaan hama yang berbeda pada petak percobaan tidak memberikan pengaruh nyata terhadap populasi ulat grayak pada pertanaman. Hal ini terjadi baik pada varietas Anjasmoro maupun pada varietas Wilis seperti yang tampak pada Gambar 5.

Hasil pengamatan terhadap populasi kutukebul menunjukkan bahwa pola pengelolaan hama yang berbeda mempengaruhi populasi kutukebul pada $21 \mathrm{HST}$ dalam percobaan varietas Anjasmoro. Populasi kutukebul paling rendah terdapat pada pengendalian hama PHT sedangkan paling tinggi terdapat pada pengendalian non-kimiawi. Gambar 6 menunjukkan bahwa populasi kutukebul pada varietas Anjasmoro menurun sejak 56 HST. Penurunan ini terjadi terus hingga 70 HST. Fluktuasi populasi tersebut berbeda dengan yang terjadi pada varietas Wilis. Populasi kutukebul dalam percobaan menggunakan varietas Wilis menunjukkan peningkatan kutukebul terjadi sejak 56 HST hingga 70 HST. Pengelolaan hama yang berbeda tidak mempengaruhi populasi kutukebul pada varietas Wilis.

Hasil pengamatan terhadap populasi kepik penghisap polong pada pertanaman kedelai varietas Anjasmoro menunjukkan tidak terdapat perbedaan pada petak dengan pola pengelolaan hama yang berbeda. Hal ini juga terjadi pada tanaman kedelai varietas Wilis. Pola pengelolaan hama yang berbeda pada petak perlakuan tidak mempengaruhi populasi kepik penghisap polong.
Hasil ini tampak pada Gambar 7 yang menunjukkan pada varietas Anjasmoro populasi kepik penghisap polong tinggi pada petak dengan pengelolaan hama PHT sedangkan pada petak dengan pengelolaan hama nonkimiawi rendah. Hasil pengamatan populasi menunjukkan bahwa kepik penghisap polong pada kedelai varietas Wilis ditemukan pada petak dengan pengelolaan hama yang berbeda dan pada petak tanpa pengelolaan hama (kontrol).

Pola pengelolaan hama yang berbeda tidak berpengaruh nyata pada populasi ulat penggerek polong yang ditemukan pada polong sampel. Hasil tersebut sama pada kedelai varietas Anjasmoro maupun pada varietas Wilis. Hasil pengamatan pada Gambar 8 menunjukkan bahwa pada varietas Anjasmoro, ulat pengerek polong ditemukan mulai pada 70 HST sedangkan pada varietas Wilis ulat pengerek polong ditemukan mulai $63 \mathrm{HST}$.

Produksi Kedelai. Produksi kedelai varietas Anjasmoro pada petak tanpa pengelolaan hama sebesar $15,5 \mathrm{~kg} / 100 \mathrm{~m}^{2}$ sedangkan pada petak dengan pengelolaan hama PHT, non-kimiawi dan kimiawi berturut-turut sebesar $16,4 \mathrm{~kg} / 100 \mathrm{~m}^{2}, 16,9 \mathrm{~kg} / 100 \mathrm{~m}^{2}$ dan $15,8 \mathrm{~kg} / 100 \mathrm{~m}^{2}$. Hasil tersebut secara statistik tidak menunjukkan perbedaan antar pola pengelolaan hama pada varietas Anjasmoro (Tabel 1). Hasil produksi kedelai varietas Wilis pada petak tanpa pengelolaan

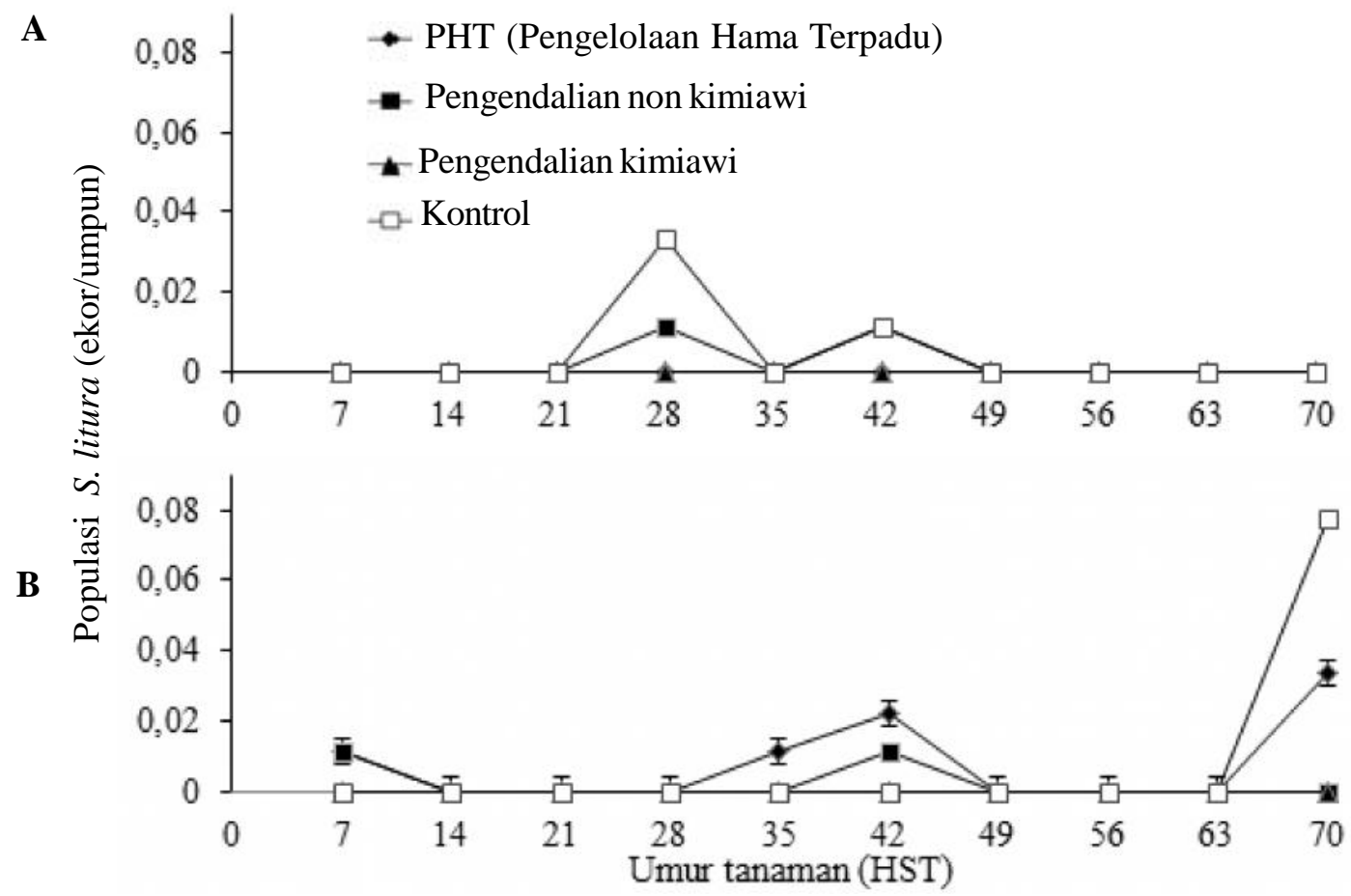

Gambar 5. Populasi kutudaun S. litura pada tanaman kedelai varietas Anjasmoro (A) dan Wilis (B) dalam petak yang menggunakan pola pengelolaan hama berbeda; Garis vertikal pada bar menunjukkan nilai galat baku 


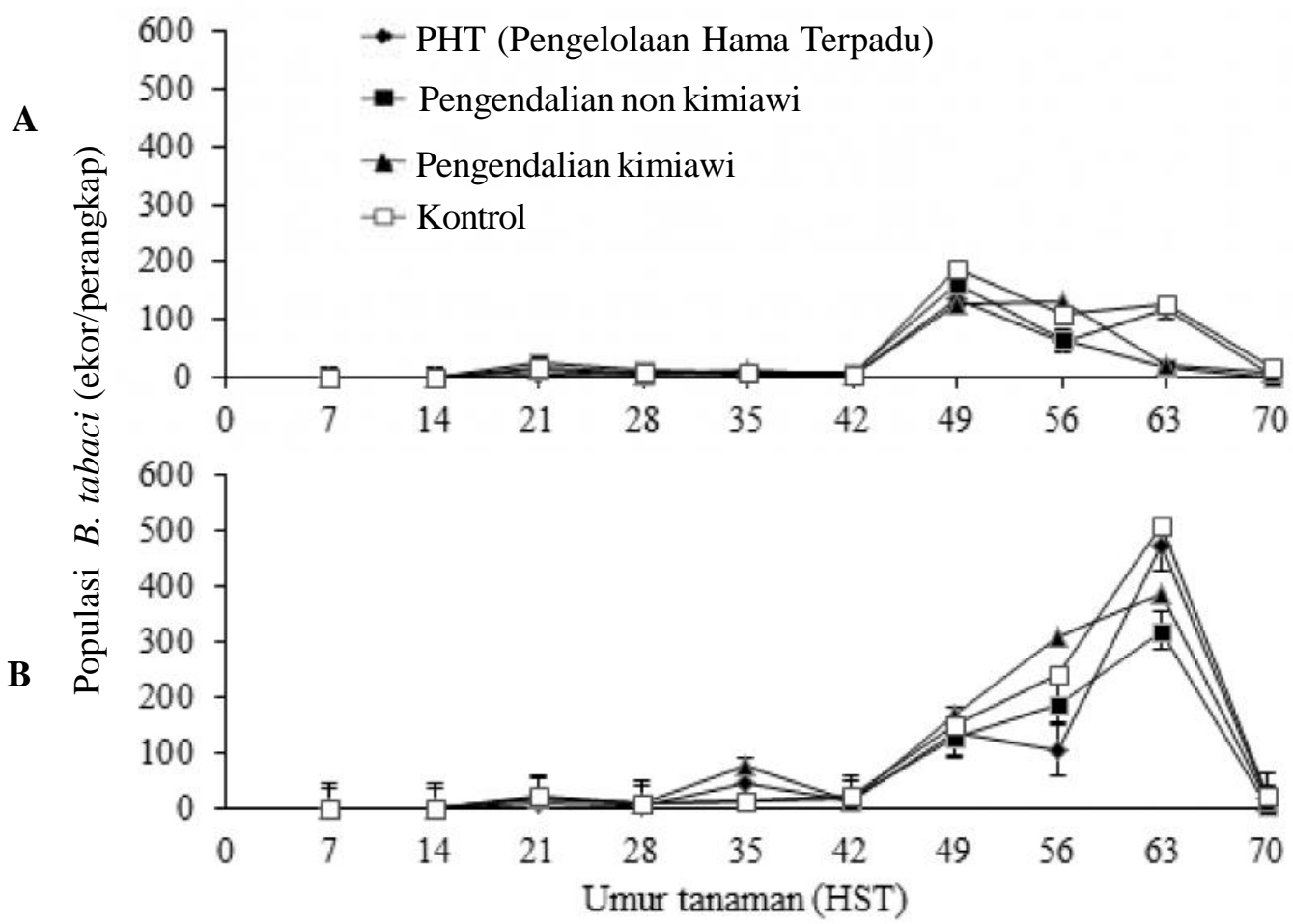

Gambar 6. Populasi kutudaun B. tabaci pada tanaman kedelai varietas Anjasmoro (A) dan Wilis (B) dalam petak yang menggunakan pola pengelolaan hama berbeda; Garis vertikal pada bar menunjukkan nilai galat baku

A

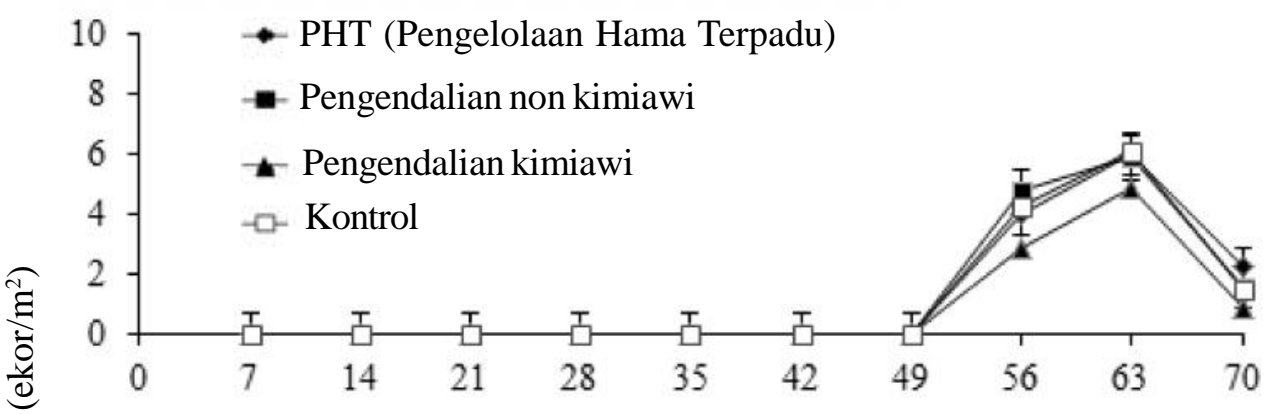

B

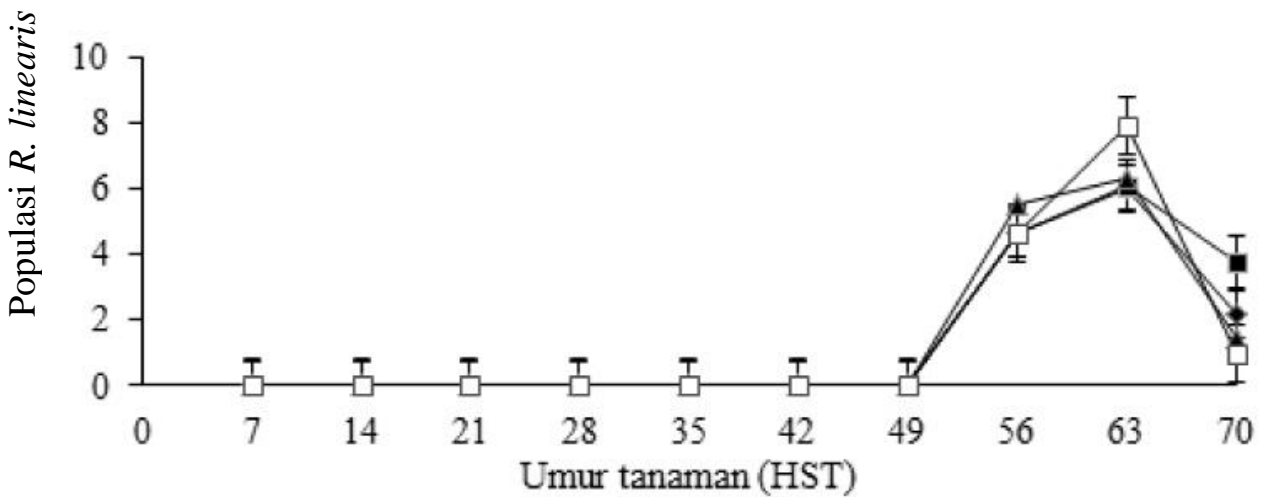

Gambar 7. Populasi kutudaun R. linearis pada tanaman kedelai varietas Anjasmoro (A) dan Wilis (B) dalam petak yang menggunakan pola pengelolaan hama berbeda; Garis vertikal pada bar menunjukkan nilai galat baku 


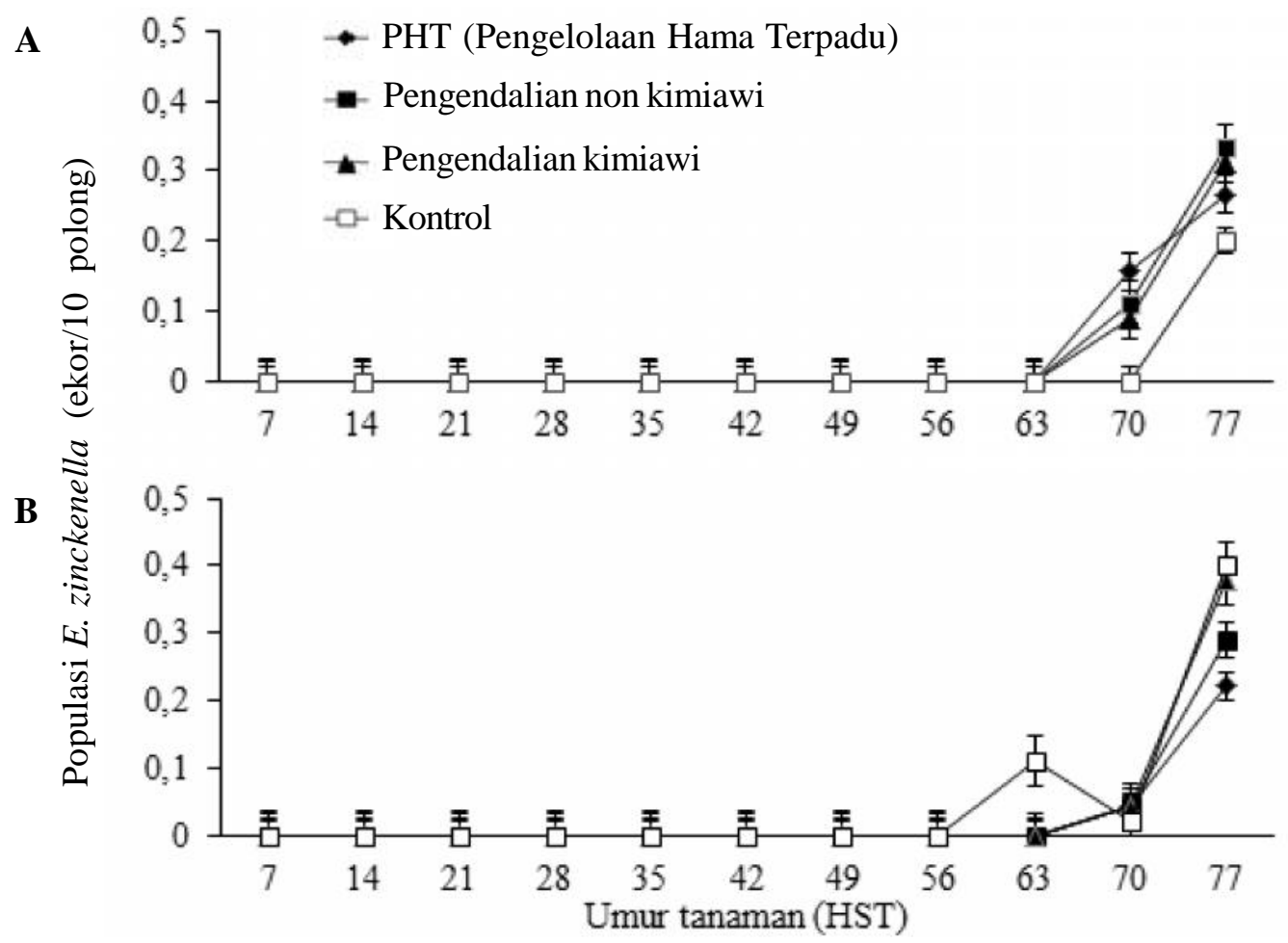

Gambar 8. Populasi kutudaun E. zinckenella pada tanaman kedelai varietas Anjasmoro (A) dan Wilis (B) dalam petak yang menggunakan pola pengelolaan hama berbeda; Garis vertikal pada bar menunjukkan nilai galat baku

Tabel 1. Produksi kedelai varietas Anjasmoro dan Wilis pada petak yang menggunakan pola pengelolaan hama yang berbeda di Ngawi

\begin{tabular}{lcc}
\hline \multirow{2}{*}{ Pola pengelolaan hama } & \multicolumn{2}{c}{ Produksi $\left(\mathrm{kg} / 100 \mathrm{~m}^{2}\right)^{\mathrm{a}}$} \\
\cline { 2 - 3 } & Varietas Anjasmoro & Varietas Wilis \\
\hline PHT & $16,4 \mathrm{a}$ & $21,9 \mathrm{ab}$ \\
Pengendalian Non Kimiawi & $16,9 \mathrm{a}$ & $21,8 \mathrm{ab}$ \\
Pengendalian Kimiawi & $15,8 \mathrm{a}$ & $23,1 \mathrm{a}$ \\
Kontrol & $15,5 \mathrm{a}$ & $20,2 \mathrm{~b}$ \\
\hline
\end{tabular}

aNilai dengan huruf yang sama pada kolom yang sama menunjukkan tidak terdapat perbedaan nyata pada uji Tukey dengan selang kepercayaan $95 \%$.

hama sebesar 20,2 $\mathrm{kg} / 100 \mathrm{~m}^{2}$ sedangkan pada petak dengan pengelolaan hama PHT, non-kimiawi dan kimiawi berturut-turut sebesar 21,9 kg/100 m²; 21,8 kg/100 m² dan $23,1 \mathrm{~kg} / 100 \mathrm{~m}^{2}$. Hasil produksi tersebut menunjukkan pola pengelolaan hama mampu meningkatkan produksi. Hasil produksi tinggi terdapat pada petak dengan pengelolaan hama PHT, kimiawi dan non-kimiawi, sedangkan terendah terdapat pada petak tanpa pengelolaan hama.

Keberadaan hama pada tanaman kedelai mempengaruhi pertumbuhan tanaman, yang pada akhirnya akan mempengaruhi produktivitas. Shepard et al. (2001) menyatakan bahwa aplikasi insektisida pada saat hama mencapai atau melebihi ambang kendali akan meminimalkan frekuensi aplikasi insektisida pada pertanaman kedelai sehingga mengurangi biaya produksi dan jumlah residu pada tanaman. Hasil pengamatan terhadap kemunculan hama pada percobaan dengan varietas Anjasmoro dan varietas Wilis menunjukkan bahwa hama lalat kacang muncul pada 14-21 HST, kemudian kutukebul, ulat penggulung daun dan ulat grayak muncul pada 21-70 HST sedangkan kutudaun, kepik penghisap polong dan ulat penggerek polong muncul pada fase generatif 42-70 HST. Hasil 
pengamatan terhadap lalat kacang, kepik penghisap polong, ulat penggerek polong dan ulat penggulung daun sesuai dengan hasil penelitian Marwoto (2007) bahwa lalat kacang menyerang pada 1-30 HST, kepik penghisap polong dan ulat penggerek polong menyerang pada 31-70 HST sedangkan ulat penggulung daun menyerang pada saat tanaman berumur 11-51 HST. Namun, kemunculan hama ulat grayak, kutukebul dan kutudaun berbeda dengan hasil penelitian Marwoto tersebut. Perbedaan ini disebabkan oleh adanya curah hujan yang tinggi pada 7-21 HST di musim tanam ini. Kemunculan kutudaun pada fase generatif didukung oleh kondisi lingkungan yang sesuai bagi perkembangannya. Faktor curah hujan juga mendukung keberadaan kutukebul pada fase vegetatif sampai dengan fase generatif tanaman kedelai. Pada musim kemarau populasi A. gossypii lebih tinggi daripada musim penghujan (Riyanto et al., 2011). Kemunculan dan populasi hama berkaitan dengan fenologi tanaman (Biswas, 2013).

Pola pengelolaan hama yang berbeda tidak mempengaruhi populasi kutudaun, ulat penggulung daun, ulat grayak, kepik penghisap polong dan ulat penggerek polong, sedangkan populasi kutukebul dipengaruhi oleh pola pengendalian yang berbeda pada 21 HST. Populasi kutukebul paling rendah terdapat pada petak dengan pola pengelolaan hama PHT. Hal ini menunjukkan bahwa penggunaan tanaman pinggir jagung sebagai alat pengendalian fisik mampu mengganggu penyebaran kutukebul pada pertanaman. Pada kedelai varietas Wilis, pola pengelolaan yang berbeda tidak mempengaruhi populasi hama utama tanaman kedelai yaitu kutudaun, kutukebul, ulat penggulung daun, ulat grayak, kepik penghisap polong dan ulat penggerek polong. Hasil pengamatan produksi kedelai menunjukkan bahwa pada percobaan dengan menggunakan varietas Anjasmoro, pola pengelolaan hama tidak mempengaruhi produksi kedelai. Namun, pada varietas Wilis pola pengelolaan hama mempengaruhi hasil produksi. Hasil produksi paling tinggi yaitu pada petak dengan pola pengelolaan hama kimiawi, namun hasil ini tidak berbeda nyata dengan hasil produksi pada petak dengan pengelolaan hama nonkimiawi dan PHT. Hal ini menunjukkan bahwa aplikasi insektisida nabati dan penggunaan agensia hayati pada pola pengelolaan hama non kimiawi serta penggunaan tanaman pinggir jagung pada pola pengelolaan PHT mampu memberikan hasil produksi yang sama dengan produksi kedelai pada petak dengan pengelolaan hama kimiawi. Sehingga dapat diketahui bahwa penggunaan insektisida secara terjadwal pada pertanaman kedelai tidak diperlukan.
Rata-rata curah hujan harian yang tinggi pada awal penanaman menyebabkan kemunculan beberapa hama terlambat. Ketidaksesuaian antara fase pertumbuhan tanaman dengan waktu infestasi hama menyebabkan keberadaan hama sedikit, sehingga permasalahan hama yang biasa dihadapi pada musim kemarau II tidak muncul pada musim kemarau II tahun ini. Rendahnya populasi hama ini menyebabkan hasil pengamatan yang diperoleh tidak menunjukkan perbedaan yang signifikan. Permasalahan yang dihadapi pada lahan sawah pada MK-II menurut Karamoy (2008) adalah adanya peningkatan serangan hama lalat kacang, persaingan dengan gulma tinggi, tingginya populasi hama penggerek batang, ulat pemakan daun, pengisap polong, dan penggerek biji. Pola pengelolaan hama PHT memiliki kemampuan yang sama dengan pola pengelolaan hama kimiawi dalam mengendalikan populasi hama, namun penggunaan insektisida kimiawi yang bijaksana pada pola pengelolaan hama PHT membuat pola ini aman bagi lingkungan.

\section{SIMPULAN}

Pola pengelolaan hama pada pertanaman kedelai varietas Anjasmoro dan varietas Wilis dapat mempengaruhi tingkat populasi hama tertentu. Produksi kedelai varietas Wilis pada petak dengan pola pengelolaan hama kimiawi sama dengan produksi kedelai pada petak dengan pengelolaan hama non kimiawi dan PHT. Pola pengelolaan hama yang efektif mengendalikan populasi hama kedelai dan aman bagi lingkungan adalah PHT.

\section{SANWACANA}

Penelitian ini didanai melalui Program KKP3N, Litbang Kementerian Pertanian, 2013 SPK No: 693/ LB.620/1.1/2/2013 dan kerjasama dengan Balai Penelitian Aneka Kacang dan Umbi serta Departemen Proteksi Tanaman, Institut Pertanian Bogor. Ucapan terima kasih juga penulis sampaikan kepada petani kedelai di KP Ngale, Ngawi, Jawa Timur.

\section{DAFTAR PUSTAKA}

Arifin M. 2012. Bioinsektisida S1NPV untuk mengendalikan ulat grayak mendukung swasembada kedelai. Peng. Inov. Pert. 5(1): 1931. 
Berg HVD, Shepard BM, \& Nasikin. 2010. Damage incidence by Etiella zinckenella in soybean in East Java, Indonesia. Int. J. Pest Manage. 44(3): 153-159.

Biswas GC \& Islam R. 2012. Infestation and management of the leaf roller (Lamprosema indicata Fab.) in soybean (Glycine max L.). Bangladesh J. Agril. Res. 37(1): 19-25.

Biswas GC. 2013. Insect pest of soybean (Glycine max L.), their nature of damage and succession with the crop stages. J. Asiat. Soc. Bangladesh Sci. 39(1): 1-8.

Ghulamahdi M, Melati M, \& Sagala D. 2009. Production of soybean varieties under saturated soil culture on tidal swamps. J. Agron. Indones. 37(3): 226232.

Indiati SW. 2014. The use of sugar apple and neem extract to control leaf eating pest on soybean. JEBAS. 2(2): 208-214.

Karamoy LT. 2008. Relationship between climate and soybean (Glycine max (L.) Merrill) growth. Soil Env. 7(1): 65-68.

Latif MA. 2013. Diversity of insect pest in soybean crop and their integrated management. Bangladesh. J. Entomol.23(2): 65-82.

Marwoto. 2007. Dukungan pengendalian hama terpadu dalam program bangkit kedelai. Iptek Tan. Pang. 2(1): 79-92.

Radiyanto I, Sodiq M, \& Nurcahyani NM. 2010. Keanekaragaman serangga hama dan musuh alami pada lahan pertanaman kedelai di Kecamatan Balong-Ponorogo. J. Entomologi Indonesia. 7(2): 116-121.
Riyanto, Herlinda S, Irsan C, \& Umayah A. 2011. Kelimpahan dan keanekaragaman spesies serangga predator dan parasitoid Aphis gossypii di Sumatera Selatan. J. HPT Tropika 11(1): 5768.

Shepard BM, Shepard EF, Carner GR, Hammig MD, Rauf A, \& Turnipseed SG. 2001. Integrated pest management reduces pesticides and production costs of vegetables and soybean in Indonesia: field studies with local farmers. J. Agromedicine. 7(3): $31-66$.

Suhartina. 2005. Deskripsi Varietas Unggul Kacangkacangan dan Umbi-umbian. Balai Penelitian Tanaman Kacang-kacangan dan Umbi-umbian, Malang, Indonesia.

Supadi. 2008. Menggalang partisipasi petani untuk meningkatkan produksi kedelai menuju swasembada. J. Litbang. Pert. 27(3): 106-111.

Tillman PG. 2014. Physical barriers for suppression of movement of adult stink bugs into cotton. J. Pest. Sci. 87(3): 419-427.

Widodo. 2006. Peran Mikroba Bermanfaat dalam Pengelolaan Terpadu Hama dan Penyakit Tanaman. Apresiasi Penanggulangan OPT Tanaman Sayuran, Nganjuk, Indonesia.

Zakaria AK, Sejati WK, \& Kustiarini R. 2010. Analisis daya saing komoditas kedelai menurut agro ekosistem: kasus di tiga provinsi di Indonesia. $J$. Agro. Ekonom. 28(1): 21-37. 